This item was submitted to Loughborough's Research Repository by the author.

Items in Figshare are protected by copyright, with all rights reserved, unless otherwise indicated.

\title{
Football sub-culture and youth politics in Algeria
}

PLEASE CITE THE PUBLISHED VERSION

http://dx.doi.org/10.1080/13629395.2012.655045

PUBLISHER

(C) Taylor \& Francis

VERSION

AM (Accepted Manuscript)

LICENCE

CC BY-NC-ND 4.0

REPOSITORY RECORD

Amara, Mahfoud. 2019. "Football Sub-culture and Youth Politics in Algeria". figshare.

https://hdl.handle.net/2134/15539. 
This item was submitted to Loughborough's Institutional Repository (https://dspace.lboro.ac.uk/) by the author and is made available under the following Creative Commons Licence conditions.

\section{creative
commons}

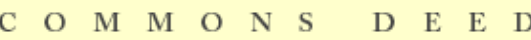

Attribution-NonCommercial-NoDerivs 2.5

You are free:

- to copy, distribute, display, and perform the work

Under the following conditions:

Attribution. You must attribute the work in the manner specified b the author or licensor.

Noncommercial. You may not use this work for commercial purposes.

No Derivative Works. You may not alter, transform, or build upon this work.

- For any reuse or distribution, you must make clear to others the license terms of this work.

- Any of these conditions can be waived if you get permission from the copyright holder.

Your fair use and other rights are in no way affected by the above.

This is a human-readable summary of the Leqal Code (the full license).

\section{Disclaimer 만}

For the full text of this licence, please go to: http://creativecommons.org/licenses/by-nc-nd/2.5/ 


\section{Football Sub-Culture and Youth Politics in Algeria}

To cite this article: Mahfoud Amara (2012): Football Sub-Culture and Youth Politics in Algeria, Mediterranean Politics, 17:1, 41-58

\section{Introduction}

The study of football offers a unique opportunity to the study of youth culture and politics in the Arab world. In general, football competitions have been used by regimes in the Arab world to legitimize their power and to distract Arab peoples from societal realities. Encouraged by the victory of a national or a local team in a regional or international competition, football fans celebrate national unity and national prestige, which is factors usually associated, according to official political discourse, with a harmonious society and the adoption of states' leaders and royal families' development policies. This phenomenon is not unique to Arab countries, however. Both democratic and authoritarian regimes, particularly during times of economic crisis or before presidential elections, integrate sport competitions (particularly football) in their public and media relations strategies in order to associate the qualification of a national football team to a major competition or the hosting of a continental or international football competition with the 'judicious' decisions of the states' leaders and the majority party in power. Illustrative examples include the victory of Argentina in the 1978 FIFA World Cup, hosted by Argentina. This victory was used by the military junta, which came to power after a military coup prior to the World Cup, to soften their international image and to legitimize their internal authority. Another example includes the 1988 Seoul Olympic Games, which was used by South Korea, under the military leadership of Chun Doo-hwan, as a showcase of the Korean economic miracle, an act of defiance to North Korea, and a distraction from the Korean population's growing discontent with the country's authoritarian regime. Last, but not least, the 1998 FIFA World Cup in France and the triumph of the French national team was promoted particularly within the right majority as an indicator of harmony in French society and the success of France's lä̈que model of integration, as symbolized by the multi-racial French national football team (bleu, blanc, beur).

Football chanting has also been used internationally as a space for social and political protestations, as well as for the expression of nationalist and xenophobic sentiments, particularly by far-right and ultra-nationalist movements in Western (e.g. France and Italy) and Eastern (e.g. 
Serbia) Europe [Giulianotti et al., 1994; Giulianotti, 1999; Bairner, 2001; Spaaij, 2006. Mignon, 1996].

In post-independence Algeria, football was used in the service of the FLN state ideology: internally, for the mobilization of social forces (youth, students, workers) to support socialism, and externally, for the integration of independent Algeria into the world's bi-polar system. It was an era of political gigantism, characterized by the development of new massive sports facilities and the participation of Algeria in major regional games (Arab, African, and Mediterranean), as well as other major international sporting events such as the Olympic Games. Sport was thus recognized by the state in the 1960s and 1970s as an effective vehicle with which to represent the Algerian socialist model of development. Starting in the 1980s, with the collapse of socialism, the football stadium became an arena for political mobilisation, or at the least a space in which to display symbols representing diverse ideological, cultural, and socio-economic claims. It has also become a place where Algerian fans 'could wear out and recreate a world according to their desires’ [Ensaad, 1998].

This paper highlights that in the current context of Algeria's political closure, which is characterized by lack of a serious political debate and a weakened civil society, a sense of a generalized disappointment with socio-economic conditions exists despite the economic boom, due to the increase of oil and gas prices in the international market. Football competitions and Web 2.0 sites have become the few possible occasions for marginalized youths to gather, feel a momentary sense of belonging, express their frustrations, mock the symbol of state authority, and transgress the boundaries of institutionalized discourse about the state's political legitimacy, morality, and nationalism. This occurs as Algeria struggles through a transition towards postconflict (following the quasi-civil war in the 1990s) and a re-organisation of power relations dominated by the coalition around President Abdel Aziz Bouteflika and corporate interests, describe by Tlemcani [2010] as neo-liberal business lobbies of import-export and bazaar economy. Meanwhile, the recent popular uprisings in the Arab world challenge the longdominated political system of party- and monarchy-states.

The paper will discuss the sub-culture of football chanting as it has existed in its many forms in Algeria, transitioning as the country moved from socialism towards a market economy, in the 1980s, and from quasi-civil war in the 1990s towards post-conflict. The last part will be devoted to an analysis of the recent phenomenon of Algerian football ultras, who have found in Web 2.0 
sites such as Youtube, Facebook, and Dailymotion a new tool to diffuse their subversive songs and to re-claim their existence, in artistic as well as in nihilistic ways.

\section{Sport and the end of socialism in Algeria}

As a consequence of the national economic crisis resulting from the reduction of oil revenues and the failure of the Algerian development programme based on heavy industrialisation and agricultural reform, the 1980s were marked by a profound transformation in Algerian society. To face the economic crisis, the state first encouraged management autonomy for large national corporations inherited from the political gigantism of the socialist era. These corporations were divided into autonomous regional entities, and became responsible for their own profitability and for finding their own supplies, sales, and financing. After 20 years of socialism and public ownership, the state project for development was reoriented towards encouraging 'controlled' liberalization, privatization, and increasing foreign investment. Thus the system of economic and social regulation administered by the state transitioned to a new system driven by market forces. Fates [1994] argued that there was a correlation between the economic crisis resulting from consecutive reductions in the price of oil, the decline in the value of the American dollar (reaching $\$ 10$ ), and the increased interest of the political establishment in sporting spectacles. According to Fates, interest in sport, particularly in football, increased to became one of the privileged domains of the presidency. The special status of sport in the political regime was clearly evident when the Ministry of Youth and Sport declared that the Algerian team's victory against West Germany in the 1982 World Cup in Spain had done more for the nation than the work of any Algerian ambassador around the world. This victory also stimulated a sense of mobilization and a nationalist feeling in Algerian society, which had never been felt since the country's independence in 1962.

In 1986, Algeria's preparation of a national football team for the World Cup in Mexico was seen as an effective ideological tool to distract the Algerian population from the country's difficult political and economic circumstances.

Algerian people are in need of some emotions that have to be procured at a price. There is no event that can provide this emotion in equal manner to that provided by sport events... In Algeria, the streets are empty on three types of occasion: at the moment of breaking the fast during Ramadan, during the broadcasting of national 
team football matches and during the final episodes of certain popular TV series. [Fates, 1994: 51, original text in French]

However, the popular mobilisation achieved by international competitions does not occur as a result of national, domestic games. State-owned media, particularly newspapers and other security sources, declared that violence at different stadia in Algeria for the 1987/88 season had officially caused the deaths of three people, with 365 injured, 127 cars damaged or completely destroyed, and 516 persons arrested. For the 1988/89 season, the same sources indicated 478 injuries, 127 cars damaged, and 451 persons arrested. Once Algeria had 20 years of independence, its football stadia were transformed into arenas for political agitation and social unrest

The sport stadia were next to register the heat of social discontent. At every football match, there were riots and youth demonstrations. The youth came from varying backgrounds, but they came together at regular intervals to poke symbolic fun at the high and mighty, sending up highfalutin official pretensions to morality in irreverent doggerel. In time such demonstrations were duly stigmatized as a threat to social harmony and unity. [Chikhi, 1991: 220]

Football matches (in addition to concerts of raï music) became one of the few occasions for thousands of youths to gather, shout openly against the regime, and present their demands. By asking in a provoking manner for housing to marry and for immigration to Europe or Australia, as well as shouting loudly the names of drugs, sometimes in the presence of senior state officials and the president himself, young people used football competitions to express their rejection of social inequalities and FLN hegemony: 'Babor l'Australie' ('We want a boat to Australia'), 'Manroubouche el l'army' ('We don't want to go to the Army'), 'Mawtini Italie' ('My nation is Italy'), 'Zetla...l'artane...temesta...6-15'.

As Evans and Phillips [2007: 114] described, 'The football terraces, encapsulating as they did the huge chasm of unforgiving contempt between the rulers and the ruled, were the harbinger of October 1988', in reference to the rioting that occurred in October 1988, known also as 'Black October'. Algerian youth took to the streets and burned down everything that symbolized for them the FLN-state (ministerial offices, city halls, FLN regional bureaus, etc.). Repression of the rioters was brutal. Unofficial estimates held that more than 500 people were killed and more than 
3,500 arrested. Following 'Black October', a new constitution was introduced and was accepted by national referendum in February 1989, to put an end to the socialist doctrine of the partystate and to FLN hegemony, as well as to offer freedom of expression and to form associations.

Since the early 1990s, Algerian football was affected by the same influences as those that Mignon [1994] describes as being pervasive in French football at the beginning of the 1990s. These influences took the form of an aspect of globalization, specific to Mediterranean football culture, that one might term 'Italianisation'. The nature of this southern European influence did not relate to the style of football played on the pitch, but rather to the way fans expressed themselves - through slogans, songs, and dress. It may have been due to the growing interest of the Algerian media in European football, particularly the Italian Serie $A$, as evidenced by the increasing time reserved for live broadcasts, reporting, and news coverage of the major European leagues. This increased interest was influenced by the launch of the Champions' League in its new, more lucrative form, with more clubs, more competition, and (therefore) more broadcasting hours.

Another factor was the growing popularity among Algerian households of satellite television channels such as TF1, France2, and Canal+, which devoted more hours to the broadcasting of sporting events (including live matches, documentaries, and analyses) as a means by which to break down the geographic isolation that Algeria was experiencing. Satellite channels were also perceived as another alternative for Algerian families to express their freedom of choice to watch programmes other than those offered by the Algerian state-controlled channel, nicknamed 'the unique' or 'El Yatima' (the orphan).

The other impact of this global culture was the development of club fan associations. Transformed by their active members with the growth of Trabendo (the Algerian black-market), club fan associations became small enterprises involved in organizing trips to attend away games, and in selling club souvenirs as well as imported counterfeit football replica of European football clubs such as FC Barcelona, Real Madrid, AC Milan, Jeventus. At the same time, Algerian football fans remain closely attached to their local clubs [Amara and Henry, 2006].

\section{Football between 'controlled democracy' and political violence, from 1992}


The failure of the 1990s Algerian economic reforms was due mostly to the country's mode of regulation, which was described by Safir [1996] as centralized regulation in an economy with problematic performance, strongly dependant on the price of oil in the world market. As a result, the country's transition towards a market economy caused rivalries and conflict, creating a situation of multidimensional crisis and deficits in the economic, social, and cultural sectors.

The political situation was not bright, either. Political violence flared after the cancellation of the 1991 legislative elections, in which the first round of voting seemed likely to produce the needed majority for the Islamic Salvation Front (FIS). This cancellation heralded the beginning of a new cycle of violence and atrocities that resulted in the deaths of hundreds of thousands of Algerians and profoundly affected all aspects of Algerian society.

While the early 1990s saw Algerian fans opening up to external influences, stadia became also used by legalized political parties as arenas for political mobilisation and demonstrations of strength during electoral campaign meetings. Inter-urban football tournaments organized during national or religious events in different cities were used as occasions to display symbols in favour of the political, ideological, and cultural claims of different parties. Sport in general and football in particular was transformed into a political and ideological subject of debate. It became a tool for ideological positioning, a way to distinguish one movement or political party from another. Such movements included the pursuit of the recognition of Amarighia (the Berber language) as an official language, as exemplified by fans' chanting in Berber 'Imazighen, Iamrighen' ('We are free, we are Amazigh'), or the pursuit of an Islamic ideal, as expressed through the chanting of 'Alyba nabya oua aliha namout' ('In the name of Allah we live and we die'), 'Qala Allah Qala Errassoul' ('No charter, no constitution, God said, the Prophet said'). The stadia were also employed to protest against the state's repression of the October 1988 riots. 'Beb El Ouad...Beb El Ouad Al choubada' ('The martyrs of Beb El Ouad'), has become a football anthem in honour of the young martyrs of post-independent Algeria. Football fans' chants range from rejecting social inequalities to contesting the regime's official discourse on morality and history.

The reigning atmosphere of insecurity and terror, particularly between 1993 and 1998, resulted in a decline in the football leagues' levels of activity and the increased instability in the organization of competitions, principally at a regional level, where weekly travel for events became dangerous for staff, players, and fans. Some well-known personalities within the media and administrative spheres, as well as ordinary football fans, became direct victims of this political violence. 
Examples of prominent football personalities who became victims include Mr Rachid Haraigue ${ }^{2}$, the president of the Algerian Football Federation assassinated on 23 January 1995, and before him the president of Bordj-Menaiel Football Club (eastern Algeria) Ali Tahanouti murdred on 5 October 1994, and Dehimi Hocine 'Yamaha', a well-known fan of the former football team Chebab Belouizded (CRB) on 11 June 1995 [Collonna, 1999; Boudjedra, 1999]. The list of victims also includes ten young fans of USMA Algiers, who were killed in Bouzéreah, one of Algiers' most popular streets, adjacent to the 5 July Olympic Stadium, while celebrating the success of their team in the 1997 Cup Final.

However, because all kinds of people have been the direct victims of this violence, we cannot assume anything regarding the political or ideological objectives behind the assassination of personalities within the football sphere. The reason may simply and sadly be that the popularity of the game and the media exposure that it attracts makes it a target for those seeking to garner broad publicity for their actions. However, despite all the violence, the Algerian Football Federation did not stop running the football leagues, and fans did not completely abandon the stadia. Similarly, the media continued coverage of the games. Under these circumstances, football became for some a symbol of resistance against political and ideological radicalism, and for others a source of distraction from the hard realities of life in Algeria ${ }^{3}$.

The chanting of fans in stadia has continued to replicate the political situation in Algeria. At a football game, you can hear, for instance, 'Ya Ali Ya Abbass El Djebha Rahi Labass' ('To Ali Belbadj and Abass Madani, in jail, the Islamic Front is fighting fit'-in other words, the FIS still exists despite the state's court decision to ban the party in 1992). You might also hear 'Flicha, Napol' (the nicknames of two Amirs of the GIA in Algiers) or 'Siminoff...Dictariov... Boufarik Patriotes' (Siminoff...Dictariov, names of Russian guns, Boufarik are all behind the patriots ${ }^{4}$ ). One can argue that football fans are torn between challenging the state's authority, or pitting themselves against what Algerians call El-hogra ('contempt')—the brutal disregard for citizens exhibited by officials at all levels of government [Tlemçani, 2008]—on the one hand, and defying the logic of violence of armed groups, on the other.

\section{Sport and the transition towards 'post-conflict'}

In November 1995, new amendments to the constitution were introduced, revising the legislation on political parties and elections and strengthening presidential powers [Aghrout and 
Zoubir, 2009]. After the short presidency of Liamine Zeroual, Abdelaziz Bouteflika was elected in 1999 and again in 20045. During these two terms, the state held referendums on civil concord in 1999 and national reconciliation in 2005, thus shifting the political debate in Algeria towards re-negotiating the understanding of 'modernism and pluralism' and 'radicalism'. Modernism and pluralism refer today to some notion of progress and controlled political pluralism as a break from 'the uncontrolled pluralism' of the 1990s, now associated with anarchy and violence. These concepts are shaped by the coalition in power, which is dominated by the nationalist wing (represented by FLN and the Nationalist Rally for Democracy [RND] parties). Founded in 1997, RND represents, for some in the opposition and independent press, FLN-bis. The alliance incorporates also the so-called moderate Islamists represented by the Movement of Society for Peace. Both wings form what is known as the 'presidential alliance'.

Radicalism, on the other hand, is now associated with those armed groups that refuse to put an end to violence and to join the platform for 'national reconciliation'.

In 2008, the presidential-alliance-dominated Algerian parliament passed a constitutional reform to allow presidents to be elected for more than two five-year terms. This allowed for the reelection of Abdelaziz Bouteflika on 9 April 2010, for a third term. His re-election coincided with favourable oil and gas pricing in the international market, which helped to fulfil one of his campaign promises concerning debt restructuring. He was able to reduce Algeria's foreign debt from $\$ 22 \mathrm{~B}$ in 2003 to $\$ 5.57 \mathrm{~B}$ at the end of 2007 . According official figures, by 2009 Algeria's hard currency reserve had attained $\$ 135 \mathrm{~B}$.

The reaffirmation of Algeria's presence and power constructed around the paradigm of civil concord and national reconciliation was also present in the sporting domain. During a speech on 23 March 2009, Abdel-Aziz Bouteflika, the then candidate for the presidential election, reminded the audience that sport practice was a refuge for youths 'who represented the brilliance of the country'. He regretted, however, that Algerian athletes were unlikely to improve the country's declining image, despite the finance and facilities provided for the general practice of sport. He even claimed that 'Algeria has the means to organize two World Cups', but he came back to ask the audience: 'Where are we today?' From 'decline to decline', he answered. He continued by stating, 'The glory of Algerian sport is fading and sport practice is witnessing increasing forms of violence. This issue could have grave repercussions if things remain as they are' [Liberté newspaper, 2009]. 
One could argue that the speech was part of an electoral campaign to convince the Algerian electorate and particularly the national sport community to vote for candidate Bouteflika for a third term, to continue his policy of national reconciliation. That being said, he was the first presidential candidate to address the question of sport in a long speech, announcing thus the beginning of a direct intervention of the presidential institution in sport affairs in general, and elite/performance sports in particular.

Despite heavy investment in mega projects for the development of infrastructures (roads, bridges, etc.) and, in diplomatic terms, the return of Algeria to the international scene 'as an active member of the international coalition for the fight against terrorism', the ingredients for political and economic instability are still perceptible according to political and economic analysts. This resulted from the quasi-control of the 'presidential alliance' over polity. As Volpi [2006] described, such quasi-control is a political system that adapted the discourse of democracy (and market economy), while ensuring that the key principles of democratic governance cannot operate to their full extent, thereby creating a situation of 'stabilized' pseudo-democracy.

In addition to feeble foreign investment, Algeria's hydrocarbon sector still accounts for more than $97 \%$ of Algeria's exports and $70 \%$ of its fiscal revenues. High levels of unemployment, along with modest salaries and purchasing power and remaining security concerns, have caused a sense of resentment among the Algerian population, particularly among the youth [AfDB/OECD, 2003]. Demonstrations of resentment have taken the form of industrial strikes led by independent trade unions in education, industry, and medical sectors, as well as successive pockets of riots in different parts of the country to protest against inequality, corruption, lack of transparency in the delivery of social housing, and uneven sharing of development projects between urban and rural areas?

Defeat in a football match or a team's relegation to a lower division can trigger violent demonstration and confrontation with security forces. Case in point: in May 2008, in the city of Oran, riots broke out in response to the relegation of Mouloudia Club Oran (MCO) to the second division. Relegation of MCO was not the only cause, however-many young fans of other, rival clubs joined the riots, which burned down banks, shopping malls, public administration buildings, and bus stops. Of the demonstrators, 120 were arrested and 300 injured; of those, 69 (including 37 minors) were judged for disturbing public order, destruction of public properties, 
and assault [El Watan newspaper, 2008]. Quotidien D'oran newspaper [2008] titled its article on the riots: 'Oran undergoes the shock wave' to describe the state of incomprehension and confusion among the population of Oran in relation to the magnitude of violence.

Other, similar incidents have taken place in different regions of Algeria, involving fans of clubs in the first league as well as those in lower divisions. In a seminar on football violence in Algeria held 25 June 2009 in Algiers, the representative of the General Direction of National Security stated that in the 2008-2009 season, 378 minors were judged for their involvement in acts of violence, 3 persons died, and 828 persons were injured, including 378 policemen, 241 supporters, and 48 referees. The damage included 323 cars, 87 belonging to police forces and 139 to private owners. In a survey undertaken from 6-8 February 2009, by two private newspapers, El Khaber (arabophone) and Liberté (francophone), 74.4 per cent of a population of 1340 youngsters aged 15-39 indicated that there is a correlation between harsh socio-economic conditions in the country and violence in football [Liberté, 2009].

The feeling of discontent with the socio-economic conditions reached its peak with the January 2011 riots, which took place in a number of Algerian provinces and caused the death of five and the injury of hundreds among protesters and police forces. According to primary estimation, the riots caused more than 1 billion Algerian Dinars (€9.84 million) of material damage. Some newspapers reported that the riots began after a post-match scuffle between fans and police in the Algerian capital [Brown, 2011]. The protesters targeted what seemed, at least from their perspective, symbols of local authority (tax offices, local councils, schools, buses, banks, etc.) and 'consumer society' (shops selling top sports brands, cars, watches, etc.) in the 'privileged', new prosperous quarters of Algiers (e.g. Sidi Yabia and Beb El Zouar).

In response to these riots, the Algerian government reduced prices for basic products such as cooking oil, sugar, and flour, and cancelled all football league matches for more than one month, in order to avoid catalysts for further protests. In an attempt to make sense of what had happened, and to de-politicize the riots, Interior Minister Oueld Kablia provided a psychoanalytic explanation for them. He stated that the riots were provoked by Algerians born in the 1990s, who are:

Extremely nihilist and pessimist. There are reasons for this, which we are aware of: lack of leisure, troubled school education, indifferent familial environment, the influence of 
the street and foreign media...they crave everything that they cannot acquire other than through stealing, smuggling, and drug trafficking. They do not find diversion in music, sport, and travel. Their universe is the street and their neighbourhoods. [Algerieplus.com, 2011, translated from French].

In this context, characterised by a lack of communication and understanding between the Algerian government (which was still dominated by the generation of pre-independence) and the Algerian youth, football stadia, coupled with Web 2.0 sites, are transformed into a space where it is possible to both mock state power and to escape from the real world and official politics [El Alaoui, 2010].

While other countries have set up monitoring or filtering programs on the grounds of maintaining state security, preserving national unity, and safeguarding public morality [Hroub, 2009], Algeria allows relatively unrestricted access to the web. Estimates hold that Algeria has 3 million internet users, including 700,000 using Broadband services, and the state holds a monopoly in the sector of internet service provision (the Algeria Telecom Company) ${ }^{8}$. This relative freeness may change with the current government's recent introduction of a new cybercrime bill to prevent hacking, theft of personal data, promotion of terrorism and crimes, blackmail, and copyright infringement. To this end, a new national security service focused on cybercrime was established [OpenNetInitiative, 2009].

\section{Babor ya babor eddeni li bled el nour... (Oh boat, take me to the country of light....)}

Recent football chants and videos posted by the football fans of famous Algerian clubs, particularly in the region of Algiers, were analysed to make sense of the Algerian youth's engagement with the current political and socio-economic situation. The phenomenon of Italianisation is apparent in the names given to the new emerging groups of young people who specialize in football chanting: Torino, Milano, ultras verde leone, Palermo, ultras irossi Algeri, etc. In opposition to fans who identify themselves with Italy and Italian clubs such as Mouloudia Club d'Alger (MCA) and Union Sportive de la Médina d'Alger (USMA), rival groups choose to identify themselves with England (such as Chebab Belouizdad [CRB]), or with Germany (such as Union Sportive de la Médina El Harrach [USMH]). Fans of USMH, a popular club from the Eastern, populated suburb of Algiers, are accused of being 'outsiders' by clubs from central Algiers. They are labelled as the 'Others' to refer in general to those on 'the periphery', 'invaders' and 
'intruders' who fled from the atrocities of mass murders during the 1990s, particularly those who fled the region of El Metidja (30 km from Algiers), which was notoriously known as the 'triangle of death"9, to settle in the eastern suburb of Algiers, around El Harrach, Beraki, Ben Talha, Eucaluptus. These rival clubs compete to form a reconstruction of the meaning and the boundaries of 'centre/insider' and 'periphery/outsider', to redefine the authentic territory of Algiers and the true inhabitants of Algiers. However, despite their rivalries, all are united in their contestation against the symbols of state power, the privileged class (i.e. the French-speaking les nouveaux riches) and the ruling elite who control the networks of politics and neo-liberal economy in Algeria.

Although the aim of this paper is not to compare how the politicising of football stadia occurs in different regions of Algeria, it could be argued that the dialectic of difference (us and them), whether constructed around territory, identity, or social/political claims, has identical codes and rules among the different regions of Algeria, although each region has a distinct culture and vernacular [Fates, 2009]. Although such discussion is not the emphasis of this paper, it should be noted that football chanting and posted videos in Algeria, much as in other countries, are filled with forms of exclusion, bigotry, hooliganism, and even self-inflicted harm. For example, one famous video on Youtube shows fans of USMH jumping in the sewage-polluted water of the Oued El Harrach river, to 'celebrate' the club's return to the first division in 2008.

The following selections of songs are widely diffused in Web 2.0. Because of their dancing bits, some have become popular beyond football sub-culture to be adopted in family wedding parties. Although the structures of these songs and posted videos may seem senseless, there are elements of creativity in the selection of lyrics, images, tones, and rhythms, and it is evident that fans create the songs in an effort to decode the perplexing situations of their daily lives, which are characterized by injustice, marginalisation, and even self-denial. The songs exhibit a willingness to provoke the establishment and to promote a form of expression that is the antithesis to the formal languages of Algeria (Arabic and French), which are languages of the elite and the state, but not of the people. This form of protest via language mirrors Benrabah's [2004] argument that, since the independence of the country in 1962, language and politics in Algeria were wedded in an indissoluble union to serve the hegemony of the ruling elite. 
For the purpose of this paper, the songs were translated from Algerian slang to English, with the intent of communicating their general sense and making them accessible to a non-Algerian audience.

\section{L'espania eddina ya Al-Babri (Take us to Spain with you, sailor)}

I am a young man...I am not educated

I want to go to Italy

I can only work as an informal parking attendant or a seller of cigarettes

This is the condition of the poor

Oh sailor, take us with you to Spain...I am suffering from headache

Europe, you are in my heart and I cannot resist

They said: Talk or pay money

Where is the right that we all share?

They said that we will buy Star Academy....

And helpless people accept their word

We only count on God

I will live in Napoli, and there I will repent

Ya al babri Ya al babri (Oh sailor...oh sailor)

Try... it is Hallal and not Haram ${ }^{10}$.

Defect [haraga] to Italy...to watch AcMilan.

Algeria my love...they said it, our ancestors:

Corruption is always around....

Defect to a foreign country-Italy, Italy...I would not give up

Roma, Malaysia...it is nice to stay in Poland.

Oh sailor, oh sailor...Allah blesses your mum.

I abhor my neighbourhood...let me go through

Visa for ten days...I do not ask for six months

Even if they give me one day, I will remain there forever.

We swear to God, we are not going to stay in this country.

\section{Fi al babor (In the boat)}

Defect one way without a return.

We will improve our lives...to Milan we certainly go. 
We will get married there...in Roma there are beautiful women.

\section{Ya les jeunes ya les jeunes (Come on, young people)}

A boat to Italy... whatever happened.

It is not safe to live in Algiers anymore... it is invaded by outsiders.

They now live in Hydra ${ }^{11}$.

We are tired... forgive me, my dear-I will change my nationality.

Oh, my mum prays for me.

Because of our enemies...we will take an Italian nationality.

\section{Fi l'Algerie maranache aichiine (In Algeria we are not alive)}

In the boat we are all living...Sardinia, we are coming.

We are the true sons of Algiers.

There, we will have a better life....

We are not scared of the Marine Corps, and to God we seek refuge.

Fans of Mouloudia left the country without a return...from Sardinia to Barcelona.

Oh, sailor takes a deposit and rendezvous tomorrow in the harbour.

I will not retreat...you will see me one day in Canada.

There I will take control...dressed only in fashionable brands.

Leave our enemy in their jealousy.

\section{Maakaditch enniiche (I cannot live here...I cannot)}

We will live a better life... defect to Italy.

I will not come back.

I cannot live in my neighbourhood...I cannot live.

I cannot live there with intruders....

The fan of Mouloudia [chenomi ${ }^{12}$ is going abroad, and he won't come back.

I will send a letter to my dad and to my mum and to those who haven't forgotten me.

Even if my life will change, I won't change my dearest Mouloudia.

A common theme of these songs is that of el-haraga. The expression comes from the Arabic word 'baraka', that is 'to burn'. It was commonly used among the general population in North Africa, and later integrated in media and academic vocabularies, to refer to 'clandestine immigration', or defection, describing the act of crossing borders and burning passports and 
other IDs after entering a European territory, either to seek asylum or to destroy any evidence about the country of origin, in order to stymie deportation procedures. Associated with this theme are the metaphors of the boat (babor) and the sailor (babri), which represent the only remaining method of accessing the impregnable fortress that is Europe, as these youngsters cannot escape through the conventional circuit of legal migration, visa application, and passport. Mobility between borders in Algeria remains a privilege for the upper class.

The songs depict geography and borders in a loose manner. They are de-constructed beyond the strict political and security definitions of territoriality. Fan songs can therefore offer (in a metaphorical sense, at least) the possibility of challenging the established borders of the nationstates and the dichotomy between 'here' and 'there'. Moreover, football chanting offers the fans independence to choose their itinerary, 'to travel from Sardinia to Barcelona, stop by Poland, before reaching the final destination, Canada or even Malaysia'. One could argue that the destination is selected for its geographic closeness; for the new possibility it provides to pass through 'to the other side', as an alternative to other congested routes for illegal immigration; for its impossibility to reach; or for its associations with popular European football clubs and brands.

Algerian football fans' determination to leave the country is also constructed around their spirituality. To fulfil their dream of crossing the sea, they seek the help of God and the blessing of the Mother. The general feeling of hopelessness in the country is replaced with the permanent endeavour of seeking happiness, salvation, and repentance of their sins elsewhere, on the other side of the Mediterranean Sea. Notwithstanding the risk of dying in the sea (which has been a reality for many) and defection's opposition to the official interpretation of Islam, which declared el-Haraga to be 'suicidal-like' and thus unlawful, fans borrow, or re-conquer, the language of Ijtibad and Fetwa, usually the domain of clerics and the Ministry of religious affairs, to justify defection as an accepted practice.

The sense of belonging of football fans is not necessarily constructed around the 'sacred' tie with the nation, but rather regards the nostalgic vision of the neighbourhood (bouma). The fans regret the decline of neighbourhood solidarity. They describe the sense of insecurity and uncertainty that is now prevalent, mourning the time when neighbours embodied the social role of an extended family. Moreover, they denounce the new borders that are now formed to separate rich and poor neighbourhoods, which are even harder to subvert than the geographical borders with 
Europe. This denunciation is in line with the results of Bouaouina's [2007] field work with inhabitants in Algiers on the historical, social, and cultural significance of the neighbourhood, which she defines as a sense of belonging to a communal identity of spatial proximity inside the social space of the town.

For the majority, houma [the neighbourhood] is not the secure urban cell where social practices favour urban integration, as it used to be. It is not the symbol of urban identity and solidarity. It is not the place where the sense of living-in maintains its significance.... The neighbourhoods where everybody knew and respected each other seem to be gone. [Bouaouina, 2007: 8, translated from French]

The loss of sense of belonging to the neighbourhood and the feeling of nostalgia around what Algiers used to be, as represented by the city's old Moresque quarter and the abandoned Casbah, is well illustrated in an article by Popelard and Vannier [2010, n.p] in Le Monde-Diplomatique:

Destroyed, pushed to the margin of the city and memory, it illustrates the distance that separates the Algiers of the 1950s-1960s — the high ground for people's emancipation in the third-world - to the Algiers of today, a capital confiscated by the oligarchy of state powers. (Translated from French)

In this context, loyalty to the football club becomes a substitute to the Algerian people's lost tie with the neighbourhood and the nation.

A socio-economic issue that is widely covered in these songs is, of course, that of unemployment. Working as unofficial parking guards, taxi drivers, or sellers of cigarettes are the only remaining opportunities for uneducated youngsters, and even educated young people who struggle to find a job. Those who can find work are often employed with low salaries [Sadek, 2010].

Chanting is an opportunity for fans to loudly decry forms of corruption in society and the monopoly of those whom they refer to as 'the intruders' and 'the enemy of the nation'- those who control the network of consumer society in post-socialist Algeria. Crossing to the other side of the sea seems the only way for the true Algérois to take their revenge against the dominant class and regain their true status as young, confident, fashionable, and seductive. For them, the 
project of getting married can only be fulfilled abroad, in Roma, Milan, Napoli, or Barcelona. The discourse of historical and political legitimacies formulated and monopolized by the ruling elite and diffused by the state-controlled TV, as for the so-called 'the odd passivity' and silence of the people, are rejected.

\section{Conclusion}

In the midst of the qualification pool for the 2010 FIFA World Cup, which opposed Algeria and Egypt, and following the media's global-coverage of the attack in Cairo against the bus that transported the Algerian national team, subsequent scenes of hostility on both sides nearly led to a quasi-diplomatic incident between the two countries. Football songs became an opportunity for Algerian youths to reconcile with their nation (as represented by the national team) and with their flag beyond the fixed boundaries of the state's official historical narrative. In other words, it was an opportunity for the Algerian youth to regain the right to interpret Algerian history and culture, and to make sense of the recent years of bloodshed and violence in Algeria. Compared to the songs related above, the new, 'patriotic' type songs were espoused by the general population, the press, and the public radio and TV stations ${ }^{13}$, as well as by the privatized music industry and corporate sponsors (among them the leading mobile telecom companies in Algeria: Qatari-Kuwaiti Nedjma and Egyptian Djez:y, the sponsors of the Algerian national football team). To expand their audience and access to official media, the writers of football songs softened their style, reducing their use of slang and sexually connotative language. The Ultras of Mouloudia (Torino) and USMA (Milano) decided to form one group, Torino-Milano, to write and record songs that celebrate the unity of the Algerian people and to end the rivalry between the two football clubs.

\section{Strong, strong, I love my country and long live to Algeria}

I want to remain in my country...I do not want to go abroad.

Brothers, we care for each other... and God is strong.

Warmth between Muslims... and Algeria is my dear.

After hardship comes the relief.

Our people are great, we are not in need-

Wherever Algerians go, they are proud and admired for it.

I will be happy and you will be happy and we will forget our grief.

We will forgive each other, and prosperity will return.

We remain in our land, the land of our ancestors. 
We forget about defection [haraga].

I prefer to grow up with my family and my friends,

Respecting my religion and fearing God.

In conclusion, football chanting is one of the few available forums for excluded youths to openly declare their resentments, to send politicized signals to society at large, and to claim their autonomy, normality, and their rights to mobility and consumption. Moreover, as an alternative to the official and rigid discourse of nationalism, football chanting is an opportunity for youths to take control of their identities by shaping them around loyalty to the local club, to their favourite foreign football clubs in Spain and Italy, or in relation to the (lost) neighbourhood. More importantly, it is a mode by which they may recover their right to speak about themselves, in their own language and codes; to interrogate history, faith, culture, and politics; and to assert the right to speak directly to decision makers without an intermediary, on behalf of, what they refer to in their songs, the 'silenced' people.

The qualification of the Algerian national team to the 2010 Football World Cup after 24 years of absence offered an opportunity for the youth and for the general population in Algeria and abroad to celebrate the country's success. It was an opportunity to re-occupy the streets and take pride in their 'Algerian-ness' after more than 10 years of quasi-civil war. However, the recent riots of January 2011 showed that the gap is still wide between the Algerian youth and the country's political elite. Sadly, outside the 'imagined elsewhere' that football chanting can provide, many deprived Algerian youth long to escape feelings of injustice and rejection via illegal immigration and self-immolation ${ }^{14}$. 


\section{References}

Amara, M., Henry, I. (2004) "Between globalization and local 'Modernity': The diffusion and modernization of football in Algeria", Soccer and Society, 5(1), pp. 1-26

AfDB/OECD (2003) African economic outlook: Algeria [online]. www.oecd.org/dataoecd/3/54/2497129.pdf (Accessed December 2010).

Aghrout, A and Zoubir, Y. (2009) Introducing Algeria's President-for-Life, Middle East Online report [online]. http://www.merip.org/mero/mero040109.html (Accessed 5 December 2010).

Algerie-plus.com (2011) Interview du ministre de l'intérieur daho ould kablia [online]. http://www.algerie-plus.com/actualite/exclusif-interview-du-ministre-de-linterieur-dahoould-kablia/ (Accessed 26 January 2011).

Bairner, A. (2001) Sport, nationalism, and globalization. Europe and North American perspectives, Albany, New York: SUNY Press.

Benrabah, M. (2004) Language and politics in Algeria, Nationalism and Ethnic Politics, 10(1), Spring, pp. 59-78.

Liberté newspaper (2009) Présidentielle : le monde du sport entre en jeu: D'anciennes gloires du football s'affichent à sétif, Monday 23 Mars, p.3

Bouaouina, N. (2007) Alger à travers sa 'houma' formation et déformation des espaces identitaires communautaires de quartier, Esprit Critique, 10(1) [online]. Available at http:/ 194.214.232.113/publications/1001/esp1001article03.pdf (accessed 3 February 2011).

Boudjedra, R. (1999) La vie à l'endroit, Paris: Lgf.

Brown, J. (2011) Algeria's Midwinter Uproar, Middle East Online Report [online]. Available at http://merip.org/mero/mero012011 (accessed 21 January 2011).

Chikhi, S. (1991) The worker, the Prince and the fact of life: The mirage of modernity in Algeria, in A. El-Kenz (Ed) Algeria: The Challenge of Modernity (London: CODEBRIA Books series).

Colonna, V. (1999) Yamaha d'Alger (Paris: TRISTRAM).

Dauchez, (1994) Rachida, lettre d'Algerie. Documentary (52 minutes). France 3: Producer les Films d'ici.

El Alaoui, H. (2010) No picnic, the dynamics of culture in the contemporary Arab world, Le Monde Diplomatique [English version, online]. Available at http://www.moulayhichamfoundation.org/ sites/default/files/No_picnic.pdf (accessed January 2011). 
El Watan newspaper (2008) Oran: 69 émentiers à la barre, Tuesday 14 octobre, p.6

Ensaad, A. (1998). Echoes from the stadium. Documentary (48 minutes), ARTICLE production.

Evans, M. and Phillips, J. (2007) Algeria: Anger of the dispossessed (London: Yale University Press).

Fates, Y. (1994) Sport et tiers monde, pratiques corporelle (Paris: Presses Université de France).

Fates, Y. (2009) Sport et politique en Algérie (Paris: L’Harmattan).

Giulianotti, R. et al. (Eds.) (1994) Football, violence and social identity (London: Routledge).

Giulianotti, R. (1999) Football: A sociology of the global game (Cambridge, UK: Polity).

Hroub, K. (2009) Internet freedom in the Arab world: Its impact, state controls, Islamisation and the overestimation of it all, IEMed Mediterranean Yearbook Med, pp. 268-271 [online]. http://www.iemed.org/anuari/2009/aarticles/a267.pdf (accessed 10 October 2010)

Libération newspaper (France) Le président de la Fédération algérienne de football, Rachid Haraigue, assassiné à Alger, 23 January 1995 [online], http://www.liberation.fr/monde/0101128058le-president-de-la-federation-algerienne-de-football-rachid-haraigue-assassine-a-alger (accessed 1 October 2010).

Liberté (2009) Sondage réalisé par Liberté et El Khabar violence dans les stades : Pourquoi ?, Tuesday 10 March [online]. Available at http://www.liberte-algerie.com/edit2.php?id=110531 (accessed 1 October 2010)

Le Quotidien d'Oran (2008) Algérie: Oran subit l'onde de choc, Les émeutes paralysent les commerces et les services, Thursday 29 May [online]. Available at http://www.afrik.com/article14413.html (accessed 10 October 2010)

Mignon, P. (1994) New supporter cultures and identity in France: The case of Paris SaintGermain, in R. Giulianotti and J. Williams (Eds.), Game Without Frontiers: Football, Identity and Modernity (Aldershot: Arena).

Mignon, P. (1996) Les maux du sport. La violence et le stade (1945 à nos jours), in P. Têtard (Ed.) Le Phénomène Sportif et la Société Française du Milieu du $19^{\text {ème }}$ Siècle à Nos Jours (France: Vuibert).

OpenNetInitiative (2009) Internet Filtering in Algeria [online]. Available at http://opennet.net/sites/opennet.net/files/ONI Algeria 2009.pdf (accessed 1 October 2010).

Popelard, A. and Vannier, P. (2010) Urbanisme, une autre bataille d'Alger, Le Monde Diplomatique [online]. Available at http://www.monde-diplomatique.fr/2010/12/POPELARD/19923 (accessed 9 March 2011).

Sadek, M. (2010) Young Algerians master the makeshift economy, Magharibia.com [online]. Available at 
http://www.magharebia.com/cocoon/awi/xhtml1/en_GB/features/awi/reportage/2010 /04/30/reportage-01 (accessed 10 August 2010).

Safir, J. (1996). Origines et dimensions international de la crise. In G. Manceron (Ed.), Algérie, comprendre la crise (Brussels: Interventions, pp. 139-154).

Spaaij, R. (2006) Understanding football hooliganism: A comparison of six Western European football clubs (Amsterdam: Amsterdam University Press).

Tlemçani, R. (2008) Algeria under Bouteflika, civil strife and national reconciliation, Carnegie Middle East Centre, 7.

Tlemçani, R. (2010) La culture de l'émeute est la seule expression politique audible, interview in El-Watan (8 February 2010), p. 8.

Volpi, F. (2006) Algeria's pseudo-democratic politics: Lessons for democratization in the Middle East, Democratization, 13(3), pp. 442-455. 


\section{Endnotes}

1 Zetla is the local name for cannabis. L'artane, temesta, 6-15 are the names of hallucinatory drugs

2 He was also a member of a political party MPR (Movement for the Republic), hostile to dialogue with Islamist movements (Liberation, 1995).

3 For an insightful depiction of Algerians', particularly women's, daily experiences with the violence that occurred during the 1990s, read 'Rachida, letter from Algeria', adapted in English by Eliza McDonald and Jo Thomas. Rachida is the mother of Salima Souakri (bronze medallist in the '91 World championship, and 5th in the Barcelona Olympics in '92), Mohamed the Islamist, and Samir the policeman (Dauchez, 1994).

4 The name given state armed groups for civil defence

5 The first and youngest Minister of Youth and Sport in post-independent Algeria, his term lasted from 1962 to 1963.

6 The Civil Harmony Law granted conditional amnesty to radical Islamists who surrendered and renounced violence. Islamist insurgents were eligible for amnesty if they fully disclosed their pasts, so long as they had not caused death or permanent injury to others, committed rape, or used explosives in places frequented by the public. Insurgents who had committed any of those crimes would receive reduced sentences, but not full amnesty (Tlemacani, 2008).

7 According to Liberté newspaper, 112,878 interventions were made by police forces to maintain order in 2010—an average of 900 public disturbances per month

8 The initiative for an open Arab internet: http://www.openarab.net/en/node/352

9 It includes towns and villages located $50 \mathrm{Km}$ from Algiers around Arabaa, Boufarik, Meftah, Chebli, Bougerra, Chrarrba and Blida 10 In Islamic culture, Hallal is 'accepted' practice and Haram is 'forbidden' practice.

11 Hydra is a rich neighbourhood of Algiers.

12 Called also echannoui, 'Chinese', in reference to their important number.

13 For the first time, bands such as Torino and Milano were invited to take part in TV programmes.

14 According to official estimates, 29 bodies of candidates to illegal immigration were found in the sea in 2005. In 2008, 61 bodies were found, and 98 bodies were found in 2007. 2008 was the most deadly, with 37\% more than 2007 (Quotidien oran, 6 December, 2010). At the time of writing this paper, 50 Algerians have followed the example of Bouzizi in Tunisia and attempted self-immolation since the beginning of 2011 [Agence France Press, 2011]. Of these, three people died from their injuries. 